\title{
KETERTARIKAN REMAJA TERHADAP KOMUNITAS PUNK
}

\author{
Mukhlis, Alma Yulianti dan Ina Sakinah \\ UIN Sultan Syarif Kasim Riau \\ email: almayulianti@rocketmail.com
}

\begin{abstract}
Abstrak
Penelitian ini bertujuan untuk mengetahui ketertarikan remaja terhadap komunitas punk. Metode kualitatif dengan wawancara, observasi dan dokumentasi digunakan untuk mengumpulkan data dengan melibatkan enam responden dari komunitas the oi atau street punk dan skinhead. Hasil penelitian menunjukkan faktor internal dan eksternal dimana faktor internal terkait dengan kebutuhan akan kebebasan, eksistensi, adanya krisis identitas diri dan saling mempengaruhi. Sementara faktor eksternal adalah ketidakharmonisan hubungan remaja dengan keluarga, pengaruh teman sebaya dan kegemaran terhadap music rock punk dan dandanan ala punk.
\end{abstract}

Kata kunci: kelompok sosial, remaja, anggota komunitas punk

\section{Abstract}

This research aims to study the teenagers interest toward punk community. Having qualitative method with interview, observation, and documentation, this research involved six respondents from the oi and skinhead community. Result shows internal and external factors in which internal factors are need for freedom, need for existence, identity crisis and influencing each others. Meanwhile external factors are unharmonious relationship with their family, peer influence and interest toward rock punk musi and punk make up.

Keywords : social group, teenagers, punk community member

\section{PENDAHULUAN}

Krisis antara identitas dengan kekacauan identitas mencapai puncaknya pada tahap remaja ini, termasuk remaja yang tergabung dalam komunitas Punk. Punk adalah perilaku yang lahir dari sifat melawan, tidak puas hati, marah dan benci pada sesuatu yang tidak pada tempatnya (sosial, ekonomi, politik dan budaya) terutama terhadap tindakan yang menindas. Penganut punk mewujudkan itu ke dalam musik dan pakaian. Mereka hidup bebas tapi tetap bertanggung jawab pada setiap pemikiran dan tindakannya. Oleh sebab itu, mereka menciptakan perlawanan yang hebat dengan realisasi musik, gaya hidup, komunitas dan kebudayaan sendiri (Widya, 2010:12).

Punk merupakan suatu fenomena budaya yang bersifat subaltern yang memberikan suatu identitas baru bagi sekelompok kaum muda, mereka berusaha mencari suatu wadah baru yang dapat menampung segala aktifitas dan ekspresinya sebagai proses pencarian identitas dirinya, yang dalam hal ini sekaligus sebagai media perlawanan terhadap berbagai aturan dan norma-norma yang terdapat dalam sistem negara, masyarakat dan bah- 
kan keluarga. Hal tersebut tercermin melalui penampilan mereka yang sangat kontradiktif dengan cara berpakaian masyarakat umum, sehingga menimbulkan kecurigaan besar bagi setiap orang yang memandang mereka (Wahyudi, 2006:10).

Jumlah anak punk di Indonesia memang tidak banyak, tetapi ketika mereka terjun ke jalanan, setiap mata tertarik untuk melirik gaya rambutnya yang Mohawk dengan warna-warna terang yang mencolok. Selain itu atribut rantai yang tergantung di saku celana, sepatu boots, kaos hitam, jaket kulit penuh badge atau peniti, serta gelang berbahan kulit besi seperti paku yang terdapat di sekelilingnya yang menghiasi pergelangan tangannya menjadi bagian yang tak terpisahkan dari busana mereka. Begitu juga dengan celana jeans super ketat yang dipadukan dengan baju lusuh, membuat image yang buruk terhadap anak punk yang anti sosial (Widya, 2010:14).

Kebanyakan anak-anak punk, sebelum mereka memilih punk sebagai ideologinya mereka sangat bingung dalam menjalani kehidupan karena mereka merasa belum menemukan jati diri, apalagi mereka tergolong kepada anak-anak yang bermasalah. Masalah yang pertama menurut para pemerhati anak adalah berkaitan dengan dirinya sendiri. Mereka masih mencari jati dirinya dalam tahapan menuju kedewasaan. Kurangnya kesiapan diri membuat mereka mengalami kebingungan dalam mencari identitasnya. Masalah kedua berkaitan dengan hubungan dengan keluarga mereka yang pada umumnya kurang harmonis. Mereka kurang mendapatkan perhatian dan kasih sayang dari keluarga, sebagai konsekuensinya mereka mencari perhatian di lingkungan sosial (http://www.riaupos.com).

Sehari-hari mereka bekerja sebagai tukang sablon, pengamen, penjaga distro dan tukang parkir bahkan beberapa dari mereka ada yang masih aktif kuliah di Universitas swasta di Pekanbaru. Saat malam hari mereka semua berkumpul di belakang pasar pusat ramayana. biasanya setiap dua bulan sekali mereka nge-street (jalan-jalan) ke berbagai daerah dengan tujuan berkumpul dengan scene-nan yang ada di daerah tersebut. Dengan berkunjung seperti ini dapat menambah erat persaudaraan mereka dan setiap bulan mereka mengadakan konser musik punk di berbagai daerah.

Berbagai permasalahan yang melatarbelakangi anak-anak punk sebelum mereka memilih untuk menjadi atau bergabung dalam komunitas anak punk tergambar dari hasil wawancara peneliti terhadap beberapa anak punk pada tanggal 8 Mei 2011 dari pukul 11.00 hingga 17.30 WIB. An salah seorang remaja putri mengatakan kepada peneliti:

"aku udah lama masuk komunitas punk, yaitu sejak ibuk aku meninggal dan bapak aku kawin lagi. Sejak itulah keluarga kami hancur. Aku ga dibolehin main sama teman-teman aku. Marahlah aku, trus aku di usir dari rumah sama bapak. Ibu tiri aku sebenarnya menahan agar aku ga pergi, tapi aku tolak dia. Aku bilang sama bapak, aku ga akan pulang lagi walaupun bapak mati."

Berbeda dengan An, Eg yang berasal dari Jakarta dan sekarang menetap di

Pekanbaru mengatakan : "papa aku kerja di luar kota, mama aku ibu rumah tangga tapi ga bisa ngurusin keluarga. Kakak dan abang udah pada nikah semua. Mereka ga pernah di rumah. Aku ga tau mau cerita sama siapa tentang masalah ku. Kalau papa pulang kerjanya marah terus. Pokoknya aku ga betah tinggal di rumah. Akhirnya aku coba-coba main ke jalanan, eh..ternyata disini aku benar-benar merasakan keluarga yang utuh walaupun kami jarang makan, semuanya di sini sama. Semuanya satu keluarga. Aku ga akan rugi berteman dengan mereka, mereka semua adalah saudara aku. 
Anak punk lain yang sempat peneliti wawancara adalah Amk (nama samaran). Ia adalah salah seorang remaja punk yang berasal dari kota Medan dan sekarang menetap di kota Pekanbaru. Ia mengatakan saat pertama kali bergabung dengan komunitas ini karena situasi di dalam keluarganya tidak kondusif, ayahnya bekerja sebagai buruh bangunan jarang pulang ke rumah dan ibunya sering ke luar malam. Ia mengatakan kepada peneliti :

"aku selalu berpindah-pindah tempat tinggal. Ayah sama ibuk selalu bertengkar. Pernah sekali aku melerai mereka berkelahi, malah aku ditampar sama bapak. Aku diusir sama bapak. Pernah bapak seminggu ga pulang aku liat ibuk dengan laki-laki lain. Langsung aku ke tempat ibuk, eh.malah aku di maki-maki sama ibuk. Akhirnya aku pergi dari rumah.. aku sama teman nyari kerja di Pekanbaru. Ngamen di simpang lampu mereah. Kenalanlah sama anak punk, diajaknya ke tempat scenan mereka. Aku merasa nyaman dan aman bersama mereka. Hidup aku bebas dan ga tertekan lagi beda waktu aku tinggal dengan orangtua dulu sampai sekarang aku ga pernah nyesal bertemu dan berteman dengan mereka. Walaupun sudah tua jiwa ku tetap punk."

SelainAmk, Ac seorang remaja punk juga mengatakan kepada peneliti mengapa mereka ingin bergabung dengan komunitas ini:

"bapak udah meninggal, Cuma ibu sendiri yang besarin aku dan adikadik. Setiap hari ibu kerja, kasihan aku liatnya. Akhirnya aku pamit sama ibuk untuk kerja. Ibuk bole-boleh aja asal bisa jaga diri. Ngamen aku di simpang lampu merah. Trus ketemulah aku sama anak-anak punk, diajaknya nge-street ke bengkulu sampe akhirnya aku bisa ada disini”.

Berdasarkan petikan wawancara terhadap anak-anak punk di atas maka dengan bergabungnya inidividu ke dalam komunitas punk mereka merasakan seperti sebuah keluarga yang utuh, saling berbagi baik suka maupun duka, merasakan kehangatan yang tidak pernah didapat dalam keluarga, merasa dilindungi, hidup bebas tanpa banyaknya aturan, pengalaman hidup yang tidak akan pernah didapat dalam keluarga, dan pemikiran yang lebih maju ke depan dalam hidupnya.

Dengan berbagai penilaian dan simbol-simbol yang melekat pada dirinya serta rutinitas yang mereka lakukan, yang menjadi pertanyaan sekarang adalah "apakah semua kondisi itu menjadi gaya dan identitas diri mereka? Apakah mereka merasa percaya diri dengan berbagai simbol yang melekat pada diri dan perilaku mereka. Apakah semua yang ada pada diri mereka saat ini akan tetap mereka pertahankan sebagai citra diri dari kepribadian mereka?", "apakah penyebab mereka tertarik bergabung dengan komunitas punk?" Inilah yang mendorong peneliti untuk melakukan penelitian lebih mendalam tentang anak-anak punk yang peneliti kemas dalam sebuah judul "ketertarikan remaja terhadap komunitas punk"

\section{Rumusan Masalah}

Berdasarkan uraian di atas, maka masalah utama dalam penelitian ini dapat dirumuskan sebagai berikut: "Bagaimana remaja tertarik bergabung dengan komunitas punk, faktor-faktor yang menyebabkan mereka bergabung dengan punk dan punk sebagai identitas diri mereka?"

\section{Tujuan Penelitian}

Penelitian ini bertujuan untuk mengetahui bagaimana gambaran proses ketertarikan remaja terhadap komunitas punk, sehingga memberikan wacana bagi masyarakat umum tentang budaya unik yaitu punk, dan juga memberikan sumbangan bagi perkembangan ilmu psikologi perkembangan dan sosial. 


\section{A. kelompok social}

Johnson\&johnson (dalam Sarwono 1999:5) merumuskan definisi kelompok sebagai berikut sebuah kelompok adalah dua individu atau lebih yang berinteraksi tatap muka (face to face interaction), yang masing-masing menyadari keanggotaannya dalam kelompok, masing-masing menyadari keberadaan orang lain yang juga anggota kelompok dan masing-masing menyadari saling ketergantungan dalam mencapai tujuan bersama.

Kelompok sosial merupakan sebuah gejala alamiah di dalam lingkaran kehidupan manusia. Hal ini dapat dilihat dalam perjalanan sejarahnya, dimana manusia saling keterkaitan dalam segi pemenuhan kebutuhan-kebutuhannya. Dari sinilah mereka terbentuk dalam sebuah kelompokkelompok sosial yang mengiringi perjalanan hidupnya. (Kamto, 2004:51)

Proses pengelompokan sosial di dalam perjalanan sejarahnya telah terbentuk melalui beberapa faktor, yaitu faktor internal dan eksternal. Kelompok sosial yang terbentuk melalui pengaruh internal, lahir dari sebuah kesadaran setiap individu untuk membangun sebuah kelompok dalam pemenuhan kebutuhan-kebutuhan yang tidak dapat terpenuhi secara individual, seperti kebutuhan pertahanan dari serangan kelompok lain. sedangkan pengelompokan yang dipengaruhi oleh faktor eksternal lahir dari proses alamiah yang tanpa melibatkan kehendak pada awal pengelompokannya. Seperti seorang bayi yang dilahirkan dalam sebuah kelompok tertentu dan dinobatkan oleh mereka sebagai bagian dari kelompok. (Kamto, 2004: 51).

Menurut Festinger, Scachter \& Black (dalam Sarwono, 1999:88), keterpaduan kelompok diawali oleh ketertarikan terhadap kelompok dan dilanjutkan dengan interaksi sosial dan tujuan-tujuan pribadi yang menuntut saling ketergantungan. Pada gilirannya kekuatan-kekuatan di lapangan itu akan menimbulkan perilaku kelompok yang berupa kesinambungan keang- gotaan dan penyesuaian terhadap standar kelompok. Keterpaduan kelompok dipengaruhi oleh hal-hal berikut Lott \& lott (dalam Sarwono 1999:89):

1. hubungan yang relatif sukarela antara orang-orang yang tidak terlalu jauh berbeda dalam hal-hal yang dapat menjauhkan antarpribadi, seperti suku atau ras.

2. Hubungan kerja sama atau kompetisi yang masih dalam batas-batas sesuai norma

3. Penerimaan oleh orang lain

4. Adanya ancaman atau bahaya dari luar yang dihadapi bersama dan untuk mengatasinya tidak dapat mengandalkan pada keterampilan atau kemampuan seseorang saja

5. Status yang homogen

6. Perilaku dan sifat-sifat pribadi yang berguna untuk memenuhi fungsi kelompok yang khusus

7. Sikap, nilai-nilai dan latar belakang yang sama dam kepribadian-kepribadian yang saling mengisi dan relevan dengan eksistensi dan tujuan kelompok

\section{B. Punk}

\section{Pengertian Punk}

Pengertian punk dalam Philosophy of Punk, (Craig O'hara, 1999 dalam Widya 2010: 118) disebutkan ada tiga.Yang pertama, punk sebagai tren remaja dalam fashion dan musik. Kedua, punk sebagai pemula yang punya keberanian memberontak, memperjuangkan kebebasan dan melakukan perubahan. Ketiga, punk sebagai bentuk perlawanan yang luar biasa karena menciptakan musik, gaya hidup, komunitas dan kebudayaan sendiri.

Punk merupakan sub-budaya yang lahir di London, inggris. Punk berasal dari kata "Public United Not Kingdom" yang berarti kesatuan suatu masyrakat di luar kerajaan (Inggris). Pada awalnya, punk adalah sebuah cabang dari 
musik rock yang digemari anak muda, kemudian berkembang melalui perkumpulan anak muda yang tidak hanya menyukai jenis musik rock tetapi juga mengusung pandangan-pandangan tertentu terkait kehidupan seperti politik, ekonomi, dan masalah sosial.

Punk berusaha menyindir para penguasa dengan caranya sendiri, melalui lagu-lagu dengan musik dan lirik yang sederhana namun terkadang kasar, beat yang cepat dan menghentak. Selain fashion yang dikenakan, tingkah laku yang mereka perlihatkan seperti potongan rambut Mohawk ala suku Indian, atau dipotong ala feathercut dan diwarnai dengan warna-warna yang terang, sepatu boots, rantai dan spike, jaket kulit, celana jeans ketat dan baju yang lusuh. Ini sikap anti kemapanan, dan anti sosial. Setiap aksesoris yang dikenakan ada maknanya. Misalnya sepatu boot yang dipakai melambangkan anti penindasan. Gembok terkatup yang digantung di pinggang menunjukkan seorang "Punkers" ingin kebebasan.

Motto dari anak "Punk" itu, Equality atau persamaan hak, D.I.Y (do it yourself) dan anti kapitalisme. "Aliran Punk lahir karena adanya persamaan terhadap jenis aliran musik Punk dan adanya gejala perasaan yang tidak puas dalam diri masing-masing. Sehingga mereka mengubah gaya hidup dengan gaya hidup Punk (Widya 2010:65).

Di Indonesia, komunitas punk yang jumlahnya mayoritas dan mendapat perhatian yang lebih dari publik adalah anak punk yang ada di jalanan. Pada umumnya, anak-anak punk tersebut berpendapat bahwa apa yang menjadi gaya hidup mereka adalah suatu kewajaran.

\section{Jenis-Jenis Punk}

Dalam dunia punk, terdapat beragam jenis punk yang mengusung ideologi berbeda-beda. Ada yang cinta damai dengan menjauhi segala bentuk kekerasan, adapula yang merasa bahwa suatu tindakan langsung memang dibutuhkan agar pesan yang ingin disampaikan benar-benar mendapat perhatian dan didengarkan. Dan berikut adalah jenis-jenis punk (Widya 2010:54):

\section{a. Anarcho punk}

Anarcho punk termasuk salah satu komunitas yang sangat keras dan idealis dengan ideologiyang mereka anut. Dapat dikatakan mereka menutup diri dengan orang lain dan kekerasan sudah menjadi bagian dari kehidupan mereka. Tidak jarang mereka juga terlibat bentrokan dengan sesama komunitas punk lainnya. Karena menurutnya kekerasan atau kerusakan adalah cara yang tepat untuk dapat diterima dalam mencapai perubahan sosial.

b. Crust punk

Anggota crust punk terkenal berpenampilan kusut dan kritikannya sangat pedas, mereka memilih hidup mengembara dan bermigrasi

c. Glam punk

Para anggota dari komunitas ini merupakan para seniman yang pengalaman sehariharinya dituangkan sendiri dalam berbagai macam karya. Mereka menjauhi perselisihan dengan sesama komunitas maupun orang lain. 
d. Nazi punk

Nazi punk merupakan minoritas terkecil di subkultur punk. Anggotanya berpaham ideologi nasionalis kulit putih yang erat kaitannya dengan skinhead kulit putih.

e. The Oi

Mereka biasanya tidur di pinggir-pinggir jalan dan mengamen. Mereka adalah aliran pekerja keras. Tetapi sering membuat keonaran di berbagai tempat.

f. Queercore

Anggotanya terdiri dari orangorang yang pada umumnya "sakit', yaitu para lesbian, homoseksual, biseksual dan para transeksual

g. Riot grrrl

Riot grrrl sering mengangkat isu-isu seperti pemerkosaan, kekerasan dalam rumah tangga, seksualitas dan pemberdayaan perempuan.

h. Scum punk

Scum punk menamakan anggotanya dengan sebutan straight edge scene. Mereka sangat peduli dengan kenyamanan, kebersihan, kebaikan moral, kesehatan dan menghargai diri sendiri juga orang lain. Mereka berusaha tidak mengkonsumsi zat-zat yang dapat merusak tubuh mereka. Hidup mereka hanya untuk hari ini, tidak terlalu memikirkan masa depan.

i. Skate punk

Dinamai skate punk karena anggotanya gemar bermain skateboard.

j. Ska punk

Ska punk merupakan gabungan antara punk dengan music asal Jamaika yang biasa disebut reggae.Mereka juga memiliki jenis tarian tersendiri yang biasa mereka sebut dengan skanking atau pogo.

\section{Ideologi yang terdapat dalam Punk}

a. DIY (Do it Yourself atau melakukan sendiri)

Dengan menganut nilai ini, punkers rela bekerja dan melakukan apa saja, menjadi pengamen, tukang parkir, buruh bangunan dan sebagainya asal tidak berada dibawah naungan atau perintah dari instasi-instasi yang menurut mereka bekerja atas kontrol kaum kapitalis.

b. Anarkisme

Anarki tidak mendukung kekerasan karena dua alasan, pertama adalah anarki untuk eksis, tidak dapat diciptakan dengan cara menghancurkan milik orang lain. kedua, anarki adalah sebuah bentuk pembebasan diri kita sendiri, dengan tidak berarti pembatasan kebebasan orang lain dan kekerasan berarti menghancurkan atau menguasai secara paksa kebebasan orang lain. sesuatu yang akan dihancurkan oleh anarkisme bukanlah orang-orangnya tetapi adalah sistem pemerintahan yang tidak adil dan sistem kapitalis yang mengeksploitasikan seseorang untuk kepentingan orang lain. (http://id.wikipedia.org/wiki/an arki).

c. Kebebasan

Nilai-nilai kebebasan yang mereka yakini berbeda, ada yang menganut nilai kebebasan dari segi dandanan, saling menghargai diantara mereka, sikap masa bodoh terhadap lingkungannya dan 
sebagainya. Banyak juga punkers yang masih sekolah ataupun bekerja, kedua lingkungan sosial tersebut tidak mungkin memberikan kebebasan bagi mereka untuk mengekspresikan ideologi mereka. di saat mereka keluar dari lingkungan sosial yang menurut mereka sangat mengikat tersebut barulah mereka mengekspresikan kebebasan mereka dengan berdandan ala punk, nongkrong di scene dengan komunitasnya.

\section{Anti kapitalisme}

Di dalam lirik-lirik punk secara terang-terangan mereka menentang kapitalisme, gaya mereka dalam bermusik sangat menunjukkan bahwa mereka adalah para pemberontak.

\section{Unity (kebersamaan)}

Pada komunitas punk, mereka sangat menjunjung tinggi nilai-nilai kebersamaan. Mereka beranggapan bahwasanya semua bangsa, ras, warna kulit dan golongan adalah salah satu kesamaan dan satu tujuan. Kebersamaan yang dimaksud adalah memiliki kesatuan yang tidak bisa dipisahkan, dalam hal ini ketika terjadi sebuah konflik dengan komunitas lain maka apabila satu anak punk dipukul maka sama dengan memukul semua anak punk.

\section{E. Equality}

Equality terlihat pada aktivitas ekonomi yang mereka lakukan. Modal usaha mereka kumpulkan bersama dan penghasilan mereka bagi rata sesuai dengan perjanjian antar mereka.

\section{Dinamika Psikologis}

Masa remaja merupakan tahapan penting dalam perkembangan hidup individu. Oleh karena itu masa remaja berkaitan erat dengan perkembangan sense of identity, yaitu perasaan atau kesadaran akan jati dirinya. Berdasarkan perspektif psikologi mengenai remaja, apabila remaja dapat memperoleh pemahaman yang baik tentang aspek pokok identitas dirinya seperti fisik, kemampuan intelektual, emosi, sikap dan nilai-nilai maka ia akan siap berfungsi dalam pergaulannya yang sehat dengan teman sebaya, keluarga dan masyarakat tanpa dibebani oleh perasaan cemas dan frustasi. Jika remaja berhasil memahami diri maka ia akan memiliki kepribadian yang sehat. Sebaliknya jika ia gagal maka dia akan mengalami kebingungan atau kekacauan. Suasana kebingungan ini berdampak kurang baik karena remaja kurang dapat menyesuaikan diri baik terhadap dirinya maupun orang lain.

Masa remaja dipandang juga sebagai periode berkembangnya kemampuan interpersonal. Oleh karena itu dorongan untuk berhubungan seksual dengan keluarga (incestuous) dire press (ditekan), maka energi seksual itu dilepas untuk membentuk pengikatan cinta kasih. Dalam proses ini, superego untuk sementara diperlemah. Dengan mengurangi pengaruh aturan super ego, remaja mungkin mengalami masalah dalam mengontrol dirinya (self control). Penekanan terhadap dorongan untuk menjalin cinta kasih secara seksual dengan keluarga, remaja menjadi bingung, merasa sendirian, dan terisolasi.

Sehingga dampak dari kebingungannya ini (confusion), mereka kembali kepada teman. Minat persahabatan ini, merupakan kesenangan "narcictic" untuk mengagumi dan mencintai orang lain yang memiliki kualitas (ciri-ciri) yang sama, diamana anak dapat memperoleh penggantinya melalui persahabatan tersebut. sikap narcistic secara lambat diganti oleh pengikatan kepada orang lain yang berarti baginya (significant other). Dalam hal ini, ego mencoba untuk mengintegrasikan pengikatan yang baru ini dengan mereduksi dorongan insting. Ego memproses testing alternatifi-alternatif 
dengan memilih antara aktif dan pasif. Pilihan ini menjadikan remaja mengalami fluktuasi dalam berperilaku, antara sensitif-koersif, hidup bekelompok-menyendiri, optimis-pesimis.

Pengalaman sejak masa kecil yang penuh konflik atau frustasi dan kurang mendapat bimbingan keagamaan akan berdampak kurang baik bagi perkembangan remaja. Remaja cenderung akan mengalami kegagalan dalam mengikuti program sekolah dan cenderung memiliki sifat pribadi: tidak jujur, rasioanalisasi (suka memberi alasan untuk menutupi kelemahan dirinya dan meremehkan otoritas atau norma. Sebaliknya, pengalaman yang menyenangkan akan mempengaruhi sifatsifat pribadi yang taat hukum dan tidak melampai batas.

Jadi, dapat dikemukakan bahwa remaja dapat dipandang telah memiliki identity yang matang apabila sudah memiliki pemahaman dan kemampuan untuk menyesuaikan diri dengan diri sendiri,peran-perannya dalam kehidupan sosial (lingkungan keluarga, sekolah atau masyarakat),dunia kerja dan nilai-nilai agama.

\section{Pertanyaan Penelitian}

Berdasarkan kerangka berpikir diatas maka muncullah pertanyaan penelitian yang akan dijadikan sebagai pedoman dalam penelitian ini. Pertanyaan penelitian tersebut berupa:Bagaimana proses remaja tertarik dengan komunitas punk, faktorfaktor yang menyebabkan mereka bergabung menjadi seorang punker dan menjadikan punk sebagai identitas diri mereka.

\section{METODE PENELITIAN}

\section{A. Jenis Dan Rancangan Penelitian}

\section{Jenis Penelitian}

Penelitian ini diarahkan untuk memahami dan mendeskripsikan ketertarikan remaja terhadap komunitas street punk di Pekanbaru. Untuk penelitian ini memerlukan pendekatan yang bersifat holistic, pendekatan ini mengasumsikan bahwa keselurahan fenomena perlu dimengerti sebagai suatu sistem yang kompleks dan bahwa yang menyeluruh tersebut lebih besar dan lebih bermakna daripada penjumlahan bagian-bagian (Patton, 1990 dalam Poerwandari, 1988:34).

Penelitian kualitatif ini menggunakan pendekatan deskriptif sebagai kerangka berfikir utama, sesuai dengan tujuan penelitian yaitu untuk memahami dan mendeskripsikan bagaimana proses transformasi identitas diri pada remaja street punk yang ada di Pekanbaru.

Penelitian kualitatif bersifat alamiah, dalam arti peneliti tidak berusaha untuk memanipulasi setting penelitian, melainkan melakukan studi terhadap suatu fenomena dalam situasi di mana fenomena tersebut ada (Poerwandari, 1998:36).

\section{Rancangan Penelitian}

Peneliti akan meneliti beberapa individu yang semuanya adalah remaja yang bergabung dalam komunitas street punk berarti mereka yang telah mengalami aktifitas, interaksi dan proses dalam suatu fenomena dengan menggunakan pendekatan kualitatif dengan metode pengumpulan data secara observasi dan wawancara mendalam (in-depth interview) untuk menggambarkan suatu fenomena.

\section{B. Subjek Dan Lokasi Penelitian}

Orang-orang yang menjadi subjek penelitian ialah orang-orang yang bergabung dalam komunitas street punk. Dari hasil wawancara eksplorasi terhadap 15 orang remaja, 
peneliti melakukan penelusuran terhadap 15 orang remaja sebagai informan awal sebelum akhirnya memilih 6 orang informan utama.

Teknik pengambilan sampel yang digunakan adalah purposive sampling.Teknik ini adalah pengambilan sampel yang digunakan dengan pertimbangan tertentu dengan berbagai kriteria yang sudah ditentukan (Sugiyono, 2009:81). Adapun kriteria partisipan dalam penelitian ini adalah:

a. Remaja yang bergabung dalam komunitas punk

b. Rambut mohawk

c. Memakai piercing

d. Pakaian lusuh

e. Memakai sepatu boots

f. Memakai tatto di tubuhnya

ketertarikan peneliti pertama kali terhadap remaja punk yang bergabung dengan komunitas punk yang selanjutnya peneliti kembangkan dan tuangkan ke dalam bentuk penelitian deskriptif kualitatif. Peneliti mengambil lokasi penelitian di jalan HOS cokroaminoto di samping pasar ramayana dengan pertimbangan bahwa peneliti akan mudah untuk mendapatkan responden.

Remaja yang bergabung dengan komunitas punk selalu berkumpul di tepi jalan HOS cokroaminoto Pekanbaru. Sehari-hari mereka tidur di tepi jalan ini. Punkers biasa menyebut jalan ini dengan sebutan scenan dan setiap malam mereka mengamen di persimpangan jalan sudirman.

Selain mengambil data di scenan, peneliti juga mengambil data di tempat kontrakan responden yaitu di jalan sekuntum percetakan KD.

Lokasi penelitian ini dilaksanakan di belakang Pasar Ramayana Kecamatan Senapelan, dimana komunitas punk Pekanbaru biasa berkumpul (scenan), taman budaya (tempat diselenggarakannya parade musik), kontrakan Lbk, percetakan KD dan Universitas Lancang Kuning yang merupakan tempat diselenggarakan acara "pekanbaru bangkit”.

\section{Teknik Pengambilan Sampel}

Menurut Sarantakos (dalam Poerwandari, 1998:52) prosedur pengambilan sampel dalam penelitian kualitatif umumnya menampilkan karakteristik :

a. Diarahkan tidak pada jumlah sampel yang besar, melainkan pada kasus-kasus tipikal sesuai kekhususan masalah penelitian.

b. Tidak ditentukan secara kaku, tetapi dapat berubah baik dalam jumlah maupun karakteristik sampelnya, sesuai dengan pemahaman konseptual yang berkembang dalam penelitian.

c. Tidak diarahkan pada keterwakilan (dalam arti jumlah/peristiwa acak) melainkan pada kecocokan konteks.

\section{Teknik Pengumpulan Data}

Penelitian ini menggunakan metode wawancara dan observasi sebagai metode pengumpulan data.

\section{Wawancara}

Wawancara adalah percakapan dan tanya jawab yang diarahkan untuk mencapai tujuan tertentu (Poerwandari, 1998:720). wawancara mendalam, yang waktunya menyesuaikan dengan aktivitas responden. Sebelum tahap pengumpulan data, peneliti mengawali dengan melakukan pendekatan kepada komunitas punk tersebut, sehingga terjalin hubungan yang baik, setelah itu peneliti menentukan responden yang akan dijadikan responden dalam penelitian yang sesuai dengan kriteria yang sudah 
ditentukan berdasarkan tema penelitian. Wawancara di dalam penelitian ini dilakukan kepada remaja yang bergabung dalam komunitas punk, untuk mendapatkan informasi bagai-mana mereka bisa bergabung dalam komunitas ini, apa perubahan yang mereka alami setelah bergabung dengan komunitas ini serta bagaimana gaya hidup para punkers dan apa pandangan mereka tentang masa depannya.

Data dari hasil wawancara mendalam ini akan menghasilkan bagaimana perasaan subjek, pengalaman hidup, dan opininya. Peneliti berpedoman kepada interview guide yang telah dipersiapkan dan tidak menutup kemungkinan untuk mengembangkan pertanyaan-pertanyaan baru.

\section{Observasi}

Banister (dalam Poerwandari, 1998:62) menyebutkan bahwa observasi selalu menjadi bagian dalam penelitian psikologi, dapat berlangsung dalam konteks laboratorium (eksperimen) maupun dalam konteks alamiah. Data tentang hal-hal yang berkaitan dengan perilaku dan keseharian para anak punk tersebut diperoleh dengan melakukan observasi atau pengamatan secara langsung terhadap kehidupan kaum punk tersebut dalam kesehariannya. Data ini akan digunakan sebagai alat cross-check terhadap hasil wawancara.

Kegiatan observasi dilakukan dengan dua cara yaitu pada saat proses wawancara dan pada saat responden melakukan aktifitas sehari-hari, pada saat wawancara berlangsung peneliti akan melakukan serangkaian observasi terhadap responden, seperti: (a) gaya berpakaian (baju, sepatu. Jaket, pakaian), (b) gaya rambut (spike, mohawk, botak), (c) asesoris

(piercing,kalung,gelang,rantai,tato ,ikat pinggang,boot). Observasi yang dilakukan dalam penelitian ini adalah bagaimana subjek berinteraksi dengan teman-teman sepermainannya.

\section{Data Sekunder/Dokumentasi}

\begin{tabular}{|c|}
\hline \begin{tabular}{lr}
\multicolumn{1}{c}{ Data } & $\mathrm{se}$ \\
dokumentasi & $\mathrm{dib}$ \\
melengkapi & $\mathrm{d}$ \\
diperlukan & $\mathrm{seb}$ \\
pendukung & $\mathrm{dal}$ \\
Data-data terseb & \\
dapat berupa lirik \\
rekaman video, st \\
asesoris-asesoris
\end{tabular} \\
\hline
\end{tabular}

\section{Teknik Analisa Data}

Data penelitian kualitatif tidak berbentuk angka, tetapi lebih banyak berupa narasi, deskripsi, cerita dokumen tertulis dan tidak tertulis (gambar,foto). Ada tiga cara yang digunakan untuk teknik analisa data kualitatif :

\section{a. Open coding}

Tahapan pertama dalam analisis data kualitatif dimulai dengan open coding yang merupakan proses mencermati data yang terkumpul. Hal ini dilakukan dengan cara mengurai, memilah, mengartikan menelaah, membandingkan dan mengkategorisasikan data yang dianalisis. Hasil proses ini adalah kategori-kategori umum atau konsep yang dapat merepresentasikan fenomena yang akan dijelaskan seluas mungkin.

\section{b. Axial Coding}

Ini merupakan suatu proses yang diarahkan untuk melihat keterlibatan antara kategori-kategori yang dihasilkan melalui proses open coding. Kategorikategori yang dihasilkan dalam open 
coding dianalisis untuk melihat pola interalisasinya, diidentifikasi kemungkinan-kemungkianan hubungan sebab akibatnya serta dianalisis pula faktorfaktor yang berhubungan dengan konteks, intervening conditions, interaksi antar faktor serta konsekuensinya. Jadi hasil akhir dari proses ini adalah ditemukannya proposisi tentang kondisi yang ada yang dapat di verivikasi ke dalam data aktual dan merupakan landasan bagi selective coding.

c. Selective coding

tahap akhir dari analisis data kualitatif adalah selective coding yang merupakan proses penyeleksi kategori pokok, kemudian secara sistematis menghubungkan kategori-kategori yang lain. Hasil akhir dari proses ini adalah suatu model empiris yang dapat digunakan untuk menjelaskan fenomena yang diteliti. Model ini merupakan hasil pokok yang ingin dicapai oleh penelitian ini.Untuk membuktikan kredibilitas data, peneliti mencoba melakukan coding secara individual. Kredibilitas data diupayakan dengan menggunakan metode triangulasi dengan menunjukkan hasil transkripsi dan hasil rekaman kaset pada partisipan.Hal ini dilakukan untuk meminimalkan subjektifitas peneliti.

\section{Pelaksanaan Penelitian}

Awal mula peneliti bertemu dengan komunitas punk pada saat band punk tampil dalam acara musik di taman budaya, peneliti mencoba untuk berkenalan dengan salah satu remaja punk yang berinisial GA. lalu keesokan harinya peneliti mencoba memberanikan diri untuk bermain di tempat biasa komunitas punk berkumpul yaitu di pasar sukaramai ramayana pekanbaru, awalnya peneliti merasa takut apabila berada di tengahtengah para the oi! Yang terkadang tidak dalam keadaan sadar sepenuhnya karena pengaruh alkohol dan obat-obatan. Tetapi sekali lagi peneliti menyadari sepenuhnya bahwa ini semua adalah bagian dari konsekuensi dari penelitian yang peneliti lakukan. Penolakan dan pandangan sinis merupakan respon awal yang sering peneliti terima, sebab paham anti media melekat kuat pada sebagian the oi! Umumnya terjadi pada the oi! Yang berasal dari Medan. Paham anti media merupakan sebuah pandangan bahwa publikasi dan media massa cenderung menampilkan sisi negatif komunitas punk, pengalaman yang tidak menyenangkan dengan wartawan dan mahasiswa yang sedang melakukan penelitian juga membuat beberapa responden asal kota Medan tidak mau membuka diri dengan peneliti.

Pengalaman awal peneliti berinteraksi dengan the oi!merasa takut, yaitu perasaan takut berhadapan dengan para the oi! yang terlihat seram dan sangar. Tetapi dengan seiring berjalannya waktu peneliti menjadi lebih terbiasa berinteraksi dengan the oi! yang menjadi subjek dalam penelitian ini. Sebagian besar the oi! yang menjadi subjek dalam penelitian ini sangat ramah dan hangat, cepat dapat mengakrabkan diri dengan peneliti namun ada juga beberapa subjek penelitian yang sedikit tertutup dan sulit untuk didekati.

Peneliti mulai merasa diterima dengan baik oleh para the oi! pada saat peneliti mengikuti acara "Pekanbaru Bangkit" pada tanggal 8 mei 2010. Proses wawancara pada penelitian ini juga mengalami kendala yaitu para the oi! merasa tidak nyaman jika harus di wawancarai secara terpisah dari temantemannya mereka lebih menyukai wawancara dengan forum diskusi. Namun, peneliti berhasil mewawancarai secara terpisah 6 orang responden.

Hambatan-hambatan yang peneliti rasakan dalam menjalani proses penelitian ini antara lain dikarenakan para the oi! tidak selalu menetap di pekanbaru, mereka selalu berpindah-pindah tempat (nye-treet) ke daerah-daerah untuk bertemu dengan the oi! yang ada di daerah tersebut. 
hambatan lain ialah kesepakatan waktu antara peneliti dan subjek penelitian. Subjek peneliti bersedia diwawancarai pada sore hingga malam hari, the oi! tidak bersedia diwawancarai di siang hari karena pagi dan siang hari adalah waktu mereka tidur setelah bekerja di malam hari hingga pagi menjelang.

Setelah semua data terkumpul yaitu data dari observasi, catatan lapangan dan wawancara peneliti mendiskusikan kembali hasilnya bersama dosen pembimbing. Tahap selanjutnya setelah semua data terkumpul maka peneliti mulai merapikan hasil observasi dan catatan lapangan serta transkrip wawancara dari masing-masing responden. Setelah itu peneliti mulai melakukan proses analisa data.

\section{HASIL PENELITIAN}

\section{Dinamika Ketertarikan Remaja Men- jadi Punk}

Seorang remaja tidak begitu saja langsung tertarik bergabung dengan budaya punk dan beralih menjadi seorang punkers, tetapi ada bebarapa faktor pendorong seorang remaja memilih punk sebagai jalan hidup mereka. Faktor tersebut dapat secara internal dan eksternal.

\section{Faktor Internal}

a. Kebutuhan Akan Kebebasan

Pencarian remaja untuk kebebasan dan rasa tanggung jawab menciptakan kebingungan dan konflik bagi banyak orangtua. Orangtua mulai melihat remaja lepas kendali dari pegangan mereka. Seringkali antisipasinya adalah dengan mengadakan pengendalian yang lebih ketat, ketika remaja mencari kebebasan dan tanggung jawab pribadi, maka semakin panas hubungan anatara orangtua dan anak, perubahan emosi dapat meyusul, dengan kedua belah pihak saling memberi ancaman hingga makian dan melakukan apa pun yang dianggap perlu untuk memperoleh kendali. Beberapa remaja menunjukkan keinginan yang sangat kuat untuk berada jauh dari orangtua sehingga mereka meninggalkan rumah dengan alasan ingin mencari sebuah kebebasan. Kebebasan adalah nilai yang paling menonjol dari semua nilai-nilai yang ada di dalam punk. Menurut mereka punk dapat mengekspresikan segala hal, baik dari segi pemikiran, perilaku, pergaulan dan style berpakaian. Akibat kebebasan yang mereka lihat sebelumnya menimbulkan ketertarikan dalam diri mereka sehingga memotivasi mereka untuk turut menyatu dengan punk, baik itu dari segi style, musik, pemikiran dan lainlain

Kebutuhan akan kebebasan menjadi salah satu penyebab remaja memilih menjadi punk sesuai dengan pernyataan DY:

"orangtuaku ga pernah bebasin aku, istilahnya disini aku nyari kebebasan. Kok kayaknya anak punk itu bebas yah..mau gaya gimana suka hatinya aja. Tapi aku ngerasa orangtua ga pernah bebasin aku? Aku kalau dirumah itu stress. Sumpah..di rumah itu aku yang namanya keluar ga pernah, Cuma di kamar, kunci pintu. Ga ada satu orang yang mau ngerti aku”. (W.1.DY.461-475)

Dirumah, DY merasa orangtuanya selalu mengekang dan tidak memberi kebebasan, akibatnya jika dirumah ia hanya di kamar mengurung diri. Menurutnya orangtua sama sekali tidak mendukung apa yang diinginkan olehnya. Itu sebabnya ia mulai mencari sesuatu yang baru di lingkungan sosialnya dan akhirnya ia mengenal dengan komunitas punk. Ia mulai kenal dengan punk saat pulang sekolah di persimpangan jalan menunggu angkutan umum. Karena selalu melihat segerombolan remaja 
punk yang sedang mengamen, terlihat kompak dan sering bercanda dengan sesama mereka, maka itulah yang membuat DY tertarik dan penasaran ingin mengenal lebih jauh tentang punk.

Menurut Ausubel (1958, dalam Santrock Adolescence,2003: 191) menyatakan bahwa semasa bayi orangtua memenuhi kebutuhan dan keinginan anak. Setelah mereka berkembang secara kognitif anak mulai menyadari bahwa mereka tidak sepenuhnya terlepas dari orangtua. Persepsi ini menciptakan semacam konflik bagi anak-anak dan mungkin menyebabkan krisis dimana harga diri mereka terancam. Satu cara anak dapat memecahkan konflik ini adalah satelisasi, istilah Ausubel untuk dilepasnya rasa kepemilikan akan kekuatan diri oleh anak dan penerimaan mereka atas ketergantungan pada orangtua. Seiring anak memasuki masa remaja, satelisasi digantikan dengan desatelisasi yang menggambarkan proses remaja untuk melepaskan diri dan bebas dari orangtua. Pada tahap akhir desatelisasi adalah resatelisasi yaitu istilah Ausubel untuk suatu bentuk awal desatelisasi dimana orangtua individu digantikan oleh individu atau kelompok lain. individu mengalami resatelisasi mengikutsertakan identitas mereka kepada identitas pasangan, identitas persaudaraan, atau kelompok sosial lainnya.

b. Kebutuhan Eksistensi

Ketika remaja dihadapkan pada suatu keseragaman yang terjadi dalam masyarakat, terkadang ada remaja yang merasa jenuh akan kesamaan tersebut baik kesamaan dalam aktivitas maupun kesamaaan dalam perilaku. Menurut sebagian besar remaja punk keseragaman itu adalah membosankan. Hal ini kemudian ditunjukkan dengan remaja tersebut berusaha untuk tampil beda dari biasanya atau dari yang lain, walaupun mereka tidak berpikir orang lain menilai mereka. Kebutuhan eksistensi diri sebagai salah satu faktor yang mendorong remaja menceburkan diri dalam kehidupan punk dapat diperhatikan dari pernyataan BB:

"Motivasi aku ya eksistensi sendiri dalam keluarga minimal aku diakui sebagai seorang punk. alhamdulillah aku diterima walaupun itu juga butuh perjuangan." (W.BB.120-125)

Sama halnya dengan BB, FJ juga ingin masuk punk karena mencari eksistensi dalam sebuah lingkungan mereka.

"orang dikatakan punk itu kalo diakui ama lingkungannya dan diakui secara pribadi, kalo ga diakui yah bukan punk".(W. FJ.720-725).

Menurut FJ bentuk pengakuan yang ada pada punk adalah aktifitas dan kelakuan. Sejauh mana sikap yang ditunjukkan oleh seorang punk, jika ia sudah bulat bertekad bergabung dengan punk maka sikapnya akan menjadi seorang punk dengan bergaya punk, memakai boot, piercing, mohawk. Menganut nilainilai punk(anarki,equality) itu adalah sebagai identitas awal agar masyarakat tahu tentang punk. Setelah bersikap seperti punk maka ia harus diakui sebagai seorang punk oleh lingkungan dengan cara nyetreet, mengikuti kegiatan punk, menulis lagu yang mengangkat kaum minoritas seperti punk itu sendiri. Jika ia mengaku sebagai seorang punk tetapi tidak menjalankan segala aktifitas dan sikap punk maka ia tidak diakui sebagai seorang punk.

c. Krisis Identitas Diri 
Remaja dalam masa transisi dapat didefinisikan sebagai suatu masa peralihan dari anak-anak menuju dewasa. Dalam masa transisi ini remaja harus berhadapan dengan berbagai macam pilihan yang semuanya itu masih tergolong baru baginya, namun secara langsung maupun tidak langsung remaja dikondisikan untuk memilih, karena remaja dituntut untuk mampu beradaptasi dengan lingkungannya.

Pada tahap pencarian identitas ini remaja membutuhkan sesuatu yang sifatnya baru, mereka memerlukan pengalaman baru yang sifatnya menantang, bebas dalam mengekspresikan kemauan-kemauan mereka termasuk hal-hal yang belum bisa diterima oleh masyarakat pada umumnya. Proses pencarian identitas diri pada remaja masih tahap meraba-raba terlebih dahulu terhadap adanya budaya baru tersebut, diikuti dengan proses mengetahui, dan kemudian diikuti dengan proses identifikasi dari budaya tersebut. Selain itu mereka akan mempertimbangkan bagaimana harus bersikap agar bisa diterima. Jika terjadi kecocokan antara idealisme dalam budaya tersebut dengan kepribadian individu, maka akan mudah diterima, namun jika selama proses meraba itu tidak mengalami kecocokan maka tidak menutup kemungkinan budaya tersebut akan ditinggalkan.

\section{Faktor Eksternal}

a. Ketidakharmonisan Hubungan Remaja dengan Keluarga

Pengaruh pada keluarga lebih kepada ketidakharmonisan hubungan antara anak dan orangtua. Ketidakharmonisan di dalam keluarga ini menyebabkan individu membutuhkan sebuah wadah yang dapat menampung dan dapat berbagi rasa dengan orang lain yang senasib dengan dirinya.
Selain itu aturan yang terlalu ketat yang diterapkan oleh orangtua terhadap anak juga dapat mempengaruhi seorang anak bergabung dengan dunia punk, kondisi remaja pada saat itu memiliki semangat muda yang tinggi, serba ingin tahu tentang dunia luar, ingin lebih banyak berekspresi, menginginkan kebebasan, tantangan, membutuhkan pengakuan dan ingin selalu mencoba hal baru yang menurut mereka menarik. Sebagai akibatnya yaitu mencoba untuk keluar dari aturan keluarga yang terasa mengikat dan membatasi. Hal ini sesuai dengan pernyataan $\mathrm{BB}$ :

$$
\text { "aku ngerasa di dalam }
$$

keluarga ga dianggap dalam konteks tanda petik. Tetap dianggap sebagai anak cuman ga mendapatkan kepercayaan trus aku ngerasa sebagai orang yang paling tua, tapi kenyataannya kok kek gini.. waktu tu pikiran aku, aku butuh lingkungan baru yang bisa nerima aku apa adanya" (W.BB 261-230)

Sebagai anak tertua dalam keluarga, BB merasa ia tidak dipercaya oleh orangtuanya, selalu diatur, orangtua menanamkan disiplin yang tinggi dan bapaknya selalu memukul jika tidak sesuai dengan keinginan hatinya. BB mempunyai seorang teman punk, ia selalu cerita masalah pribadinya dengan temannya itu hingga akhirnya temannya meminjamkan kaset punk pada BB dan mengajak BB bergabung dengan punk. Proses perubahan BB tidak semudah itu, pilihannya hidup di jalanan ditentang oleh ayahnya, hingga BB berontak dan melawan.

"aku disuruh ikut les, pulang sekolah langsung pulang, ga boleh keluar malam... kalo ada kawan yang datang harus di atur waktunya satu jam..aku ngerasa orangtua terlalu ngatur. Ngatur tu boleh tapi 
lihat dulu seperti apa. Aku mikir kalo kek gini trus aku ga tahan. Mending aku bilang ama bapak, eh udah aku bilang aku ga suka diatur malah bapak marah-marah, nampar. Mending keluar aja dari rumah.." (W.BB. 225)

Kejadian itu membuat BB menjadi semakin termotivasi untuk menunjukkan kepada orangtua bahwa ia mampu bertahan hidup tanpa aturan-aturan yang dibuat oleh mereka. ia semakin bersemangat untuk bekerja membiayai kuliahnya. Dukungan dari teman-teman membuat BB semakin loyal terhadap punk yang telah banyak membantu BB sehingga ia dapat membuka usaha percetakan sendiri.

Apa yang mendorong BB bergabung dengan punk sama halnya dengan $\mathrm{AN}$, ia keluar dari rumah karena kebenciannya pada ibu tiri dan ayahnya. Ia selalu dimarahi, dibentak jika ada suatu kesalahan yang dibuatnya seperti bermain dengan teman-temannya, tidak mengerjakan pekerjaan rumah bahkan jika AN ingin membayar uang sekolah ayahnya langsung membentak dan menempeleng AN.

"aku tinggal ama bapak dirumah. Semenjak ibuk meninggal, bapak kawin lagi. Udah muak aku tinggal ma orang tu.. aku sering dipukul ama bapak, disuruh masak, cuci piring, pokoknya ga boleh keluar rumah. mina uang sekolah aja dibentak ma bapak, karna udah ga tahan dirumah lagi yah berontaklah..sakit rasanya kak..akhirnya aku lawan aja dia. Pokoknya sejak ada istri baru bapak, keluarga kami hancur".(W.AN.881891)

AN merasa tersiksa, ketakutan dan mulai timbul kebencian pada ayahnya. Berbeda ketika ibunya masih hidup kedua orangtua AN sangat menyayanginya, sekarang figur seorang ayah yang dirasakannya sewaktu ibunya masih ada telah berubah menjadi ayah yang menurutnya kejam. Sehingga membuat AN mencari tempat di luar yang bisa membuatnya nyaman, aman dan bahagia.

" ini yang aku rasa aku nyaman disini...(W.AN. 941-945)

"aku merasa bersyukur udah gabung dengan punk. disini aku punya teman,abang,kakak.. buruk kata kalo aku dicoel paling ga ada yang belain”. (W.AN. 926-930)

AN merasa punk adalah keluaraga baru yang sangat menjaga AN dengan baik dan ia patut merasa bersyukur bergabung dengan punk dan di dalam punk ia menemukan keluarga baru.

Keluarga sangat memberi pengaruh penting terhadap perkembangan anak, ketidakmatangan dalam hubungan keluarga seperti pertengkaran dengan anggotaanggota keluarga, membuat komentar-komentar yang merendahkan penampilan atau perilaku anggota keluarga sering terjadi selama tahun-tahun awal masa remaja. Pada saat ini hubunganhubungan keluarga biasanya berada pada titik rendah. Seperti yang diungkapkan BB pada peneliti:

"kalau dirumah aku harus nurutin apa yang orangtua mau, aku harus masuk sekolah ini, aku harus pulang jam segini, aku ga boleh keluar malam. Banyaklah aturan yang ngekang... aku tahan Cuma ampe kelas dua SMA, setelah itu aku mulai ngelawan, pualng malam...(W.BB.330-335)

BB merasa orangtua tidak mengerti apa yang dia inginkan, semuanya serba diatur dan orangtua selalu memaksakan kehendaknya, sehingga $\mathrm{BB}$ merasa tidak lagi 
nyaman saat berada di rumah yang akhirnya ia mulai melawan dan berontak. BB memutuskan untuk keluar dari rumah dan mencari kehidupan luar rumah yang dapat mendukungnya.

Hubungan keluarga yang buruk merupakan bahaya psikologis pada setiap usia, terlebih selama masa remaja karena mereka sangat tidak percaya diri dan bergantung pada keluarga untuk mendapatkan rasa aman. Kalau hubungan keluarga ditandai dengan pertentangan, pertengkaran dan perasaan-perasaan tidak aman berlangsung lama maka remaja kurang memiliki kesempatan untuk mengembangkan pola perilaku yang tenang dan matang.

Akibat dari ketidakharmonisan hubungan antara orangtua dan anak, yang selalu mengekang mereka menyebabkan rasa ingin tahu yang lebih besar dan muncullah sikap memberontak terhadap apa yang dikatakan oleh orangtua. Perdebatan yang hebat memunculkan rasa ketidaksenangan, merasa tertekan, tidak dihargai oleh orangtua sehingga membuat remaja ingin bertanggung jawab terhadap dirinya sendiri, merasa mampu berdiri sendiri dan ingin bebas dari kekangan orangtua.

b. Teman sebaya atau Significant Other

Karena remaja lebih banyak berada di luar rumah bersama dengan teman-teman sebaya sebagai kelompok, maka dapatlah dimengerti bahwa pengaruh teman-teman sebaya pada sikap, pembicaraan, minat, penampilan dan perilaku lebih besar daripada pengaruh keluarga.

Seorang individu akan lebih mudah terpengaruh oleh kelompok teman sebayanya, apabila tingkat interaksi dalam keluarga rendah, baik kualitas maupun kuantitasnya. Pengaruh dari teman sebaya ini menjadi faktor yang sangat menentukan seorang anak mau menggeluti dunia punk. Hal itu bisa terjadi karena dalam setiap proses interaksi selalu terjadi proses saling mempengaruhi antara individu yang satu dengan yang lain. Seperti dikemukakan BGS, AD dan BB:

"aku emang suka ama dandanannya, gayanya. Lagipula aku juga punya teman anak punk di palembang dulu. Aku juga sering nongkrong ama mereka" (W.Bgs.1020)

"kalo kenalnya udah lama, teman-teman aku anak punk semua. Rumah aku kan dekat pasar waktu di medan. Jadi mainnya ama mereka aja. Sering nongkrong diajak minumminum..ngikut. (W.AD.2155-2160)

"teman minjamin kaset punk......trus rumah $k u$ yang lama kan dekat persimpangan tuh, yah akhirnya coba nongkrong-nongkrong ternyata nyambung. Mereka asyik..”. (W.BB.50-55)

"pulang sekolah kan jalan kaki tuh ama teman-teman ke simpang jalan buat nunggu bis, nah disitu aku lihat banyak orang, banyak anakanak di situ, aku sambil nunggu bis di situ mereka ngajak ngobrol toh mpe tiap hari ketemu pulang sekolah jadi aku ngerasa ga takut lagi. Mereka ngajak ngobrol aku, akhirnya ya aku kebawa ama obrolan mereka. Orangnya asyik. Akhirnya ya senang-senag aja temenan ama mereka. Sampe ada salah satu dari mereka yang nembak aku..lagian dirumah juga ada masalah. Aku coba ikut-ikutan gabung dulu aja ma mereka. Ya akhirnya ampe sekarang masih tetap di punk".(W.DY.450-460)

BGS, DY, BB dan AD mempunyai teman yang juga seorang punk, setiap hari mereka selalu berkumpul bersama, sering 
mengikuti acara-acara punk sehingga pertemanan mereka dengan anak punk semakin erat, begitu juga dengan AD jika anak punk itu minum-minuman keras dan memakai narkoba mereka juga pasti akan mengikutinya tanpa memperdulikan perasaan mereka sendiri akan akibatnya. Karena mereka sering bertemu anak punk setiap hari, mereka juga ingin mendapatkan pengakuan dalam kelompok punk maka, mereka harus nye-treet untuk memperkuat ikatan pertemanan mereka sehingga mereka jarang berada di rumah lebih sering berada di luar. Akhirnya mereka memutuskan untuk keluar dari rumah, seperti hasil wawancara Bgs:

"tapi palingan kalo ibuk ku nyari tinggal sms suruh pulang. Kalo ibuk sms yah tinggal bilang aja lagi disini(pekanbaru). Lagian orangtuaku juga bebasin anak-anaknya kalo udah lama ga pulang palingan di suruh pulang. Trus aku pergi lagi. Yah gitu ajalah.." (W.bgs.10801085)

Masalah yang terjadi anatara anak dan orangtua biasanya disikapi oleh remaja dengan cara memutuskan untuk keluar dari rumah dan hidup terpisah dari orangtua sebagai bentuk perlawanan bagi remaja. Pilihan hidup terpisah dengan orangtua seperti yang ditunjukkan remaja punk (Bgs,BB,AD,DY,AN,FJ) memiliki konsekuensi psikologis yang berkaitan dengan kebutuhan kelekatan pada significant other. Remaja dapat mengalihkan obyek lekatnya dari orangtua kepada teman-temannya sehingga terjadi saling ketergantungan antara anak dan teman-temannya. Sebagian besar remaja mengetahui bahwa bila mereka memakai model pakaian yang sama dengan pakaian anggota kelompok, maka kesempatan baginya untuk diterima oleh kelompok menjadi lebih besar (Hurlock 1980:213) seperti penjelasan FJ:

"tiga SMP udah mulai make jeans ketat, boots waktu itu belum ada yang ajarin, ketemulah anak punk asli. Ngikutin stylenya dia, diajarin..style aslinya seperti ini gini gitu, di jalan begini,bacaannya begini, keluar kotalah lihat-lihat.." (W.FJ.665-675)

Kedekatan antara remaja dengan teman-temannya cenderung membuat mereka melakukan apa seperti yang temannya lakukan tanpa melihat akibatnya. Kelompok sebaya memberikan sebuah dunia tempat remaja dapat melakukan sosialisasi dalam suasana dimana nilai-nilai yang berlaku bukanlah nilai-nilai yang ditetapkan oleh orang dewasa melainkan oleh teman-teman seusianya. Jadi, di dalam pertemanan ini remaja dapat memperoleh dukungan untuk memperjuangkan apa yang diyakininya dan di situlah remaja dapat menemukan dunia yang memungkinkannya bertindak sebagai pemimpin apabila ia mampu melakukannya. Remaja bergabung dengan kelompok sebayanya yang "menganggap", mengerti akan dirinya, mempunyai pengalaman yang sama. Dalam kelompok remaja bisa melampiaskan perasaan tertekan yang selama ini dirasakannya karena tidak mengerti dan tidak dianggap oleh keluarganya.

Teman sebaya menyediakan sarana untuk perbandingan secara sosial dan sumber informassi tentang dunia luar di luar keluarga. Hubungan teman sebaya yang baik mungkin diperlukan untuk perkembangan sosial yang normal pada masa remaja. Pengaruh teman sebaya itu bisa bersifat positif 
maupun negatif. Menurut Sullivan (dalam Hurlock:2003:228)ada peningkatan yang tinggi secara psikologis dan keakraban antar teman dekat pada masa awal remaja. Dia menyatakan bahwa semua orang memiliki sejumlah kebutuhan sosial dasar, juga termasuk kebutuhan kasih sayang (ikatan yang aman), teman yang menyenangkan, penerimaan oleh lingkungan sosial, keakraban dan hubungan seksual ini akan menentukan kesejahteraan emosi remaja. Jika remaja gagal untuk membentuk persahabatan yang akrab mereka akan mengalami perasaan kesepian diikuti dengan rasa harga diri yang menurun.

c. Ketertarikan Remaja Terhadap Musik dan Punker Fashion

Gaya pakaian, dandanan rambut, segala macam aksesori yang menempel, selera musik atau pilihan kegiatan yang dilakukan adalah suatu bentuk perwujudan dari identitas atau kepribadian seorang individu maupun kelompok atau komunitas. Pilihan ingin tampil seperti siapa atau apa atau justru bisa menciptakan sendiri gaya yang unik dan berbeda, bahkan jika perlu, yang belum pernah digunakan oleh orang lain merupakan hak setiap orang. Begitu pula dengan gaya punk yang memiliki cara sendiri untuk menampilkan kepribadian dari scenenya masing-masing, seperti yang dijelaskan oleh BB:

"teman aku minjamin kaset punk, band asal jakarta. Dari situ aku suka, diputarin berkali-kali, kok aku ngerasa enak,nyaman ya dengarnya. Syairnya tu...pas buat aku."

BB mengaku ia merasa sangat nyaman mendengar musik rock punk, setiap hari ia selalu memutar musik punk yang didapat dari kawannya yang juga anak punk.
Terkadang BB juga meminjam fanzine sejenis majalah punk dan sering bertukar pikiran tentang punk, lama kelamaan BB mencoba bergabung dengan punk. Setelah kurang lebih empat tahun bergabung dengan punk, BB merasa punk adalah keluarganya walaupun terkadang ada perselisihan antar mereka, namun itu bukan berarti BB keluar dari komunitas ini. Setelah bergabung dengan punk ia merasa kini hidupnya adalah bagian dari keluarga punk dan ia merasa puas dan bahagia atas pilihan hidupnya saat ini. Hal yang sama terjadi pada FJ,dimana ia mulai tertarik dengan punk karena sangat menyukai musik punk, seperti yang dikatakannya pada peneliti:

"suka ama style dan musik nya. Trus kebetulan punya teman punk juga dekat rumah, awalnya mikir asyik juga neh..gayanya. trus dipinjemin kaset, yah jadi sering dengar.kadang juga nyari-nyari di internet tentang punk" (W.FJ 730735).

FJ mulai menyukai punk karena mendengar musik dan fashion punk, lalu mencoba-coba berpakaian ala punk dan bergabung dengan punk. FJ bergabung dengan punk pada tahun 2007, dan ibunya tidak melarang FJ bergaul dengan punk asalkan tidak melanggar normanorma agama. Sekarang FJ telah bergabung dengan punk aliran skinhead, gaya berpakaian skinhead dengan street punk jauh berbeda. Jika street punk terkesan kumuh dan bau yang menyengat skinhead lebih rapi dan bersih, ibu FJ sangat menyetujui penampilan FJ yang baru.

Sama halnya dengan BB dan FJ, Bgs pun demikian. Ia mulai tertarik dengan punk karena musik dan lirik-lirik lagu punk yang 
bertemakan masalah sosial. Orangtua Bgs juga tidak mempermasalahkan pilihan anaknya, mereka membebaskan tindakan yang diambil oleh anaknya asal bisa mempertanggung jawabkannya sendiri. Berikutpernyataan BGS:

"aku emang suka ama dandanannya,gayanya. Lagipula aku punya teman dekat anak punk waktu di Palembang kak. Aku sering nongkrong ama mereka, jadi udah taulah isi-isi preman-preman tuh..,tampangnya mang kayak gitu. Tapi kalo solidaritasnya ga akan ada yang bisa lawan. Aku jamin" (W.Bgs.1020)

"Ya bolehlah (ibunya memperbolehkan), aku anak cowok kok. Bebas mau ngapain aja, asal ga nyuri,nyopet itu baru dilarang. Lagipula keluarga aku bebasin aku mau ngapain..yah palingan nasehatinnya Cuma gitu-gitu aja". (W.Bgs 1021-1025)

Bgs sangat menyukai punk, salah satunya karena kegemaran terhadap musik dan gaya punk, ini kemudian diaktualisasikan melalui identitas diri yang ditampilkan dalam perilaku sehari-hari seperti cara berpakaian yang berbeda dengan remaja lainnya, yang pada akhirnya membuahkan model perilaku sebagai trend yang sekarang banyak dijumpai. Selain itu juga, perilaku seperti ini mendorong mereka untuk selalu berada di scene dan mengenakan atribut-atribut punk sebagai sebuah gaya yang digemarinya untuk menunjukkan identitas sebagai seorang punkers.

Lirik lagu merupakan salah satu sarana untuk menyampaikan pesan ke penontonnya. Lirik lagu juga merupakan bagaimana para punkers menyikapi berbagai isu-isu yang terjadi dan juga sebagai media propaganda. Para pemain musik berusaha menampilkan performance yang terbaik dan para penonton aktif mengikuti irama dari musik tersebut. Hal ini ditunjukkan dari suasana panggung yang begitu meriah, yaitu adanya berbagai macam aksi panggung dari penonton dan pemain. Aksi panggung itu diikuti dengan tarian pogo, slamdance dan moshing. Tari-tarian tersebut mencerminkan semangat jiwa anak muda yang membara, namun terkadang ada beberapa punkers yang memanfaatkan situasi itu sebagai ajang untuk mencari masalah, sehingga berbuntut keributan antar scene, karena sudah terbawa pada situasi mabuk yang tidak terkontrol, tapi punkers yang seperti ini biasanya kemudian dijauhi oleh punkers lainnya.

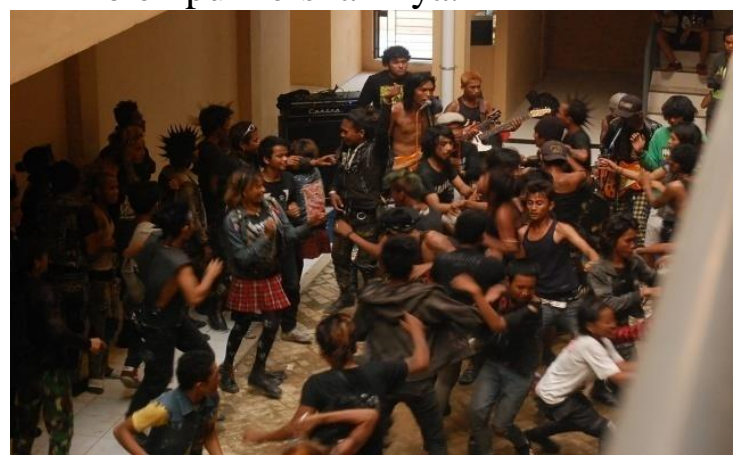

Gambar 4.1 tarian khas punk (pogo)

\section{Hasil Observasi}

1. Tujuan observasi:

Bertujuan untuk meng-cross-check hasil wawancara mengenai ketertarikan remaja terhadap komunitas punk

2. Tempat:

Kampus UNILAK, Taman Budaya dan Gor Tribuana

3. Waktu:

8Mei dan 21 november, dan Januari 2012

4. Hasil pengamatan:

Pegelaran musik punk selalu diadakan tiap bulan oleh scene daerah masingmasing dengan biaya yang dikumpulkan dengan hasil mengamen (Do it yourself). Jika salah satu scene mengadakan acara maka scene dari daerah lain juga datang, 
disanalah mereka bisa berjumpa dengan teman-teman punk lainnya. Pagelaran musik tersebut didominasi oleh kaum remaja, yang rata-rata mengenakan atribut dan aksesorisnya, serta tidak ketinggalan dengan rambut mohawk, maupun rambut skinhead.

Pada saat acara berlangsung mreka berkumpul berdasarkan scene masingmasing dan ada juga yang menggelar barang dagangannya seperti: emblem, CD, gelang, kalung dan lain-lain. Mereka menjajakan barang dagangannya bagai pedagang lapak yang membentangkan tikar untuk memamerkan barang dagangannya.

Lagu yang biasanya dibawakan oleh remaja punk bertemakan politik, yang mengecam pemerintah dan mengentaskan kemiskinan. Menurut mereka lirik lagu merupakan cara mereka berorasi dalam menyampaikan ketidakpuasan mereka terhadap situasi dan kondisi negara saat ini.

Para penonton sangat bersemangat mengikuti irama musik yang ditampilkan dari band punk tersebut, dilihat dari banyaknya aksi panggung dan pemain yang ikut menari, seperti pogo dan slamdance. Tari-tarian tersebut mencerminkan semangat jiwa yang membara, mereka sangat bersemangat dan antusias dalam setiap acara. Sewaktu mereka mengikuti taria-tarian, tidak ada tampak wajah yang melelahkan seakan semangat dan kondisi tubuh mereka sangat bergairah itu merupakan salah satu pengaruh minuman keras dan pengaruh obat-obatan yang mereka konsumsi sebelum dimulai acara.

\section{Analisis}

Berdasarkan penjelasan tema dan pola yang ditemukan, disusun bagan dinamika psikologis ketertarikan remaja bergabung dengan komunitas punk. Dalam penelitian ini menemukan beberapa aspek yang mempengaruhi penyebab ketertarikan remaja terhadap komunitas punk. Faktorfaktor yang menyebabkan remaja menjadi seorang punk salah satunya adalah faktor yang berasal dari lingkungan keluarga, remaja merasa tidak didukung, tidak difasilitasi, diacuhkan dan pengaruh pola asuh terhadap anak dapat mengakibatkan jarak yang terbentang luas antara anak dan orangtua. Intinya adanya ketidakharmonisan antara remaja dengan keluarga.

Pengasuhan yang tepat terhadap anak jika orangtua paham dan mengerti akan keadaan perkembangan si remaja dapat membimbing anak, mengarahkan serta memfasilitasi segala kebutuhan anak mereka akan merasa betah dan nyaman saat berada di lingkungan keluarga, mereka tumbuh dengan rasa percaya diri sedangkan pengasuhan yang salah terhadap anak atau yang bersifat menghukum dan memberi contoh yang buruk pada si anak maka anak akan mudah putus asa, cemas, memiliki kemampuan komunikasi yang rendah, bahkan bisa menjurus pada kenakalan remaja.

Menurut Baumrind(dalam Santrock 2003:186) bahwa orangtua seharusnya tidak bersikap mengadili maupun menjauhi remaja, tetapi sebaliknya membuat peraturan-peraturan yang tidak mengomando dan menyayangi mereka. Baurind menekankan tiga jenis cara menjadi orangtua dalam berhubungan dengan aspek-aspek yang berbeda dalam perilaku sosial remaja yaitu pengasuhan autoritatif mendorong remaja untuk bebas tetapi tetap memberikan batasan dan mengendalikan tindakan-tindakan mereka. Komunikasi verbal timbal balik bisa berlangsung dengan bebas, dan orangtua bersikap hangat dan bersifat membesarkan hati remaja. Pengasuhan autoritatif berkaitan dengan perilaku sosial remaja yang kompeten. Pengasuhan autoritarian, adalah gaya yang membatasi dan bersifat menghukum yang mendesak remaja untuk mengikuti petunjuk orangtua dan untuk menghormati pekerjaan dan usaha. Orangtua yang bersifat autoritarian membuat batasan dan kendali yang tegas terhadap remaja dan hanya melakukan sedikit komunikasi verbal. Pengasuhan 
autoritarian berkaitan dengan perilaku sosial remaja yang tidak cakap. Pengasuhan permisif-memanjakan dan bersifat permisif tidak peduli, gaya pengasuhan permisif tidak peduli adalah suatu pola di mana orangtua sangat tidak ikut campur dalam kehidupan remaja. Hal ini berkaitan dengan perilaku sosial remaja yang tidak cakap, terutama kurangnya pengendalian diri. Remaja sangat membutuhkan perhatian orangtua mereka, remaja yang orangtuanya bersifat permisiftidak peduli mendapat kesan bahwa aspek lain dari kehidupan orangtua lebih penting daripada si remaja. Remaja yang orangtua bersifat permisif-tidak peduli biasanya tidak cakap secara sosial, mereka menunjukkan pengendalian diri yang buruk dan tidak bisa menangani kebebasan dengan baik.

Orangtua yang mendukung, mebimbing dalam proses perkembangan remaja akan menghasilkan anak yang percaya diri, kecakapan sosial yang baik dalam masyarakat dan mampu menghargai diri mereka sendiri juga akan mendapatkan kenyamanan dalam lingkungan keluarga sehingga remaja tidak mencari pengakuan di luar keluarganya. Remaja yang bergabung dengan punk, mereka merasa dihargai dan menemukan komunitas yang dapat menerima mereka apa adanya. Remaja yang bergabung dengan komunitas punk merasakan sebuah keluarga yang baru dan mereka merasa nyaman saat berada dalam lingkungan komunitasnya. Remaja yang bergabung dengan punk merasakan kepuasan setelah bergabung, kepuasan yang didapat berupa hidupnya tidak terkekang (bebas), dapat menyalurkan hobby, bertemu dengan teman-teman punk daerah lainnya, dihargai, mendapatkan pengakuan di lingkungan teman sebaya, merasa percaya diri dan bangga karena dukungan dari teman-teman.

Pengaruh yang lebih besar dibanding lingkungan lainnya adalah banyak remaja menghabiskan waktu dengan teman sebaya dibandingkan dengan keluarga sehingga memunculkan konformitas terhadap teman sebaya. Konformitas terhadap teman sebaya pada remaja dapat menjadi positif atau negatif. Hampir semua remaja mengikuti tekanan teman sebaya dan lingkungan sosial, beberapa remaja ada juga yang nonkonformis/antikonformis. Perbedaan antara nonkonformis dengan antikonformis, nonkonformis adalah remaja yang mandiri yang memilih untuk tidak menjadi anggota dari perkumpulan, sedangkan antikonformitas muncul ketika individu bereaksi menolak terhadap harapan kelompok dan kemudian dengan sengaja menjauh dari tindakan atau kepercayaan yang dianut oleh kelompok seperti skinheads dan punk. Tekanan teman sebaya merupakan hal yang wajar pada usia mereka, termasuk pilihan akan baju yang ingin dipakai, musik yang ingin didengarkan, tindakan apa yang akan dipilih. Perubahan perkembangan yang terjadi pada remaja kadang membawa rasa tidak aman. Para remaja sangat mudah terganggu karena rasa tidak aman tersebut dan banyaknya perubahan perkembangan yang terjadi dalam kehidupan mereka (Santrock, 2003:223).

Beberapa ahli juga menggambarkan budaya teman sebaya remaja sebagai pengaruh merusak yang mengabaikan nilai-nilai dan kontrol orangtua, teman sebaya juga dapat mengenalkan remaja dengan alkohol, obat-obatan, kenakalan dan bentuk tingkah laku lain yang dianggap oleh orang dewasa sebagai tingkah maladaptif. Kedekatan antara remaja dan teman-temannya cenderung berperilaku seperti teman-temannya, meskipun perbuatan yang melanggar norma-norma sosial dan agama. Seperti yang dijelaskan Sullivan (dalam Hurlock,2003:228) dalam usia remaja, mereka ingin berhubungan akrab dengan teman-temannya, termasuk ingin memakai pakaian yang menunjukkan ciri mereka, aksesoris yang dipakai dan jika remaja gagal dalam membentuk persahabatan yang akrab mereka akan mengalami 
perasaan kesepian diikuti dengan rasa harga diri yang menurun. Segala perilaku yang dilakukan oleh teman-temannya selalu ingin diikutinya, walaupun itu salah. Remaja bergabung dengan teman sebaya, karena ia merasa ia tidak dimengerti, "tidak dianggap"oleh orangtuanya dan saudara-saudaranya sehingga remaja mencari di luar lingkungan keluarga yang mengerti akan dirinya, menganggap dan dalam pengalaman yang sama. Dalam kelompok teman sebaya ini, remaja bisa mengeluarkan segala keluh kesah dan perasaan tertekan saat berada di rumah.

Penelitian ini juga menemukan faktor yang berasal dari dalam diri remaja itu sendiri yaitu kebebasan. Pada masa ini perubahan fisik berubah, keingintahuan semakin meningkat, emosi menjadi labil, sehingga muncul suatu tindakan pemberontakan yang dilakukan oleh remaja terhadap orangtua, jika tidak sesuai dengan apa yang diinginkannya. Remaja merasa terkekang saat berada di rumah, rasa ingin tahu remaja tidak tersalurkan dengan baik. Berbeda jika keluarga yang sehat secara psikologis akan menyesuaikan diri dengan desakan remaja untuk mencari kebebasan, memperlakukan remaja secara lebih dewasa dan mengikutsertakan remaja dalam pengambilan keputusan keluarga. Sedangkan keluarga yang tidak sehat secara psikologis seringkali mengomando dan mengharuskan segala apa yang diperintahkan oleh orangtua yang berorientasi pada kekuasaan, orangtua lebih cenderung menggunakan bentuk otoriter dalam hubunganya dengan remaja. Orangtua yang bersifat dingin atau membiarkan anak tanpa pengasuhan yang baik juga akan mempengaruhi kepribadian remaja.( Santrock 2003:188).

Selain keinginan untuk bebas, keinginan untuk mendapatkan eksistensi sangat mempengaruhi remaja tertarik bergabung dengan punk. Kebutuhan akan eksistensi sangat dibutuhkan pada masamasa remaja. Pengakuan di dalam keluarga itu dinilai dengan rasa kepercayaan terhadap anak dan menghargai keputusan yang mereka ambil, jika anak selalu berada di dalam rasa ketidaknyamanan dan sering merasa tertekan maka ia merasa tidak diacuhkan dan tidak diakui sebagai anggota keluarga, maka pelariannya adalah mencari eksistensi diluar lingkungan keluarga yaitu lingkungan teman sebaya yang dapat menerima segala keterbatasan mereka.

Selain dari faktor keluarga, kebebasan dan eksistensi, ketertarikan remaja terhadap musik dan fashion punk juga sangat mempengaruhi mengapa remaja tertarik bergabung dengan punk. Remaja banyak menghabiskan waktu mendengarkan musik kesukaan mereka, selera musik semakin spesifik dan terdiferensiasi mulai dari awal hingga akhir masa remaja (christenson dan Roberts,1991 dalam Santrock:318). Musik memenuhi beberapa kebutuhan pribadi dan sosial remaja, kebutuhan pribadi yang paling penting adalah pengendalian prasaan dan menghilangkan kejenuhan. Musik rock seperti punk menjadi trend di kalangan remaja, musik rock ini dapat mempengaruhi pikiran dan perilaku remaja, lirik musik rock berbahaya membentuk pikiran remaja yang mengarah pada moralitas seksual,kekerasan,obatobatan dan sanatisme (Cocks, 1985 dalam Santrock 2003:319).

Punk identik dengan musik yang keras dan lirik yang menggaungkan sebuah protes, sehingga mulai bermunculan bandband yang mengemukakan kepahitan hidup dan kemarahan terhadap sebuah sistem yang ada. Band ini dipelopori oleh anakanak muda yang memang korban dari penindasan sebuah sistem, mereka biasanya menciptakan band yang agresi, keras, dan berantakan. Lirik tersebut berisi protes menentang sistem-sistem pemerintahan. Gaya mereka dalam bermusik sangat menunjukkan bahwa mereka adalah para pemberontak. (Wahyudi 2006:39) 
Bagi seorang punkers, dandanan yang mereka kenakan menjadi sebuah simbol kesamaan yang mereka anut, dandanan yang mencolok juga mereka anggap sebagai attitude yang membedakan mereka dengan masyarakat yang lain, sehingga style ini menjadi simbolis pemersatu diantara mereka. Di sisi lain, dandanan dan perilaku mereka saat berada di scene tersebut juga akan menjadi alat memperkenalkan komunitas tersebut kepada orang lain sehingga banyak remaja di luar mereka yang kemudian menjadi tertarik menjadi punkers karena dandanan yang mencolok ini.

Disini akan dijelaskan proses remaja tertarik bergabung dengan komunitas punk berasal dari ketidakharmonisan hubungan antara orangtua dan remaja. Orangtua tidak memberikan sebuah wadah bagi remaja untuk dapat lebih mengembangkan diri, karena pada saat-saat pertumbuhan inilah remaja perlu dukungan dan perhatian orangtua agar perkembangan selanjutnya tidak mengalami gangguan. Ketidakharmonisan hubungan antara orangtua dan anak menyebabkan remaja membutuhkan suatu wadah yang dapat menampung dan dapat berbagi rasa dengan remaja lainnya yang senasib dengan dirinya.

Selain itu aturan yang terlalu ketat yang diterapkan oleh orangtua terhadap anak juga dapat mempengaruhi seorang anak menerjuni dunia punk. Kondisi remaja pada saat itu memeiliki semangat muda yang tinggi, serba ingin tahu tentang dunia luar, ingin lebih banyak berekspresi, menginginkan kebebasan, tantangan, mebutuhkan pengakuan dan ingin selalu mencoba hal baru yang menurut mereka menarik. Sebagai akibatnya yaitu mencoba untuk keluar dari aturan keluarga yang terasa mengikat dan membatasi.

Pada akhirnya mereka mencari dunia luar yang dapat menerima mereka apa adanya, yaitu lingkungan teman sebaya. Remaja banyak menghabiskan waktu bersama teman-temannya, maka pengaruh teman sebaya pada remaja sangatlah besar dibanding pengaruh keluarga, karena sesuai dengan perkembangannya pada usia remaja keingintahuan yang sangat tinggi membuat remaja rela melakukan apa saja, walaupun itu melanggar norma agama maupun norma sosial.

Pengaruh dari teman sebaya inilah yang menyebabkan remaja bergabung dengan komunitas punk. Hal ini dapat terjadi karena dalam setiap proses interaksi selalu terjadi proses saling mempengaruhi antara individu satu dengan yang lain. Faktor yang mendasari proses interaksi ini adalah pertama, faktor imitasi, yaitu dorongan untuk meniru orang lain. Yang kedua,faktor sugesti yaitu adanya pengaruh psikis baik yang datang dari diri sendiri maupun dari orang lain, yang pada umumnya diterima tanpa adanya daya kritik. Ketiga, dorongan untuk menjadi identik (sama) dengan orang lain seperti halnya bergaya ala punk dan kegemaran terhadap musik rock punk yang diaktualisasikan menjadi identitas diri mereka yang ditampilkan dalam perilaku sehari-hari dengan cara berpakaian yang berbeda dengan remaja lainnya, yang akhirnya membuahkan model perilaku sebagai trend yang sekarang banyak dijumpai. Selain itu juga, perilaku seperti ini mendorong mereka untuk selalu berada di scene dan mengenakan atribut-atribut punk sebagai sebuah gaya yang digemarinya untuk menunjukkan identitas diri sebagai seorang punkers. Berdasarkan uraian diatas maka dapat disimpulkan bahwa remaja tertarik bergabung dengan punk disebabkan oleh dua faktor, yang pertama berasal dari luar remaja dipengaruhi oleh ketidakharmonisan hubungan keluarga, teman sebaya dan ketertarikan terhadap style dan musik punk dan diikuti dengan faktor dalam diri remaja, yaitu ingin merasa bebas tanpa aturan dan kebutuhan akan eksistensi. 


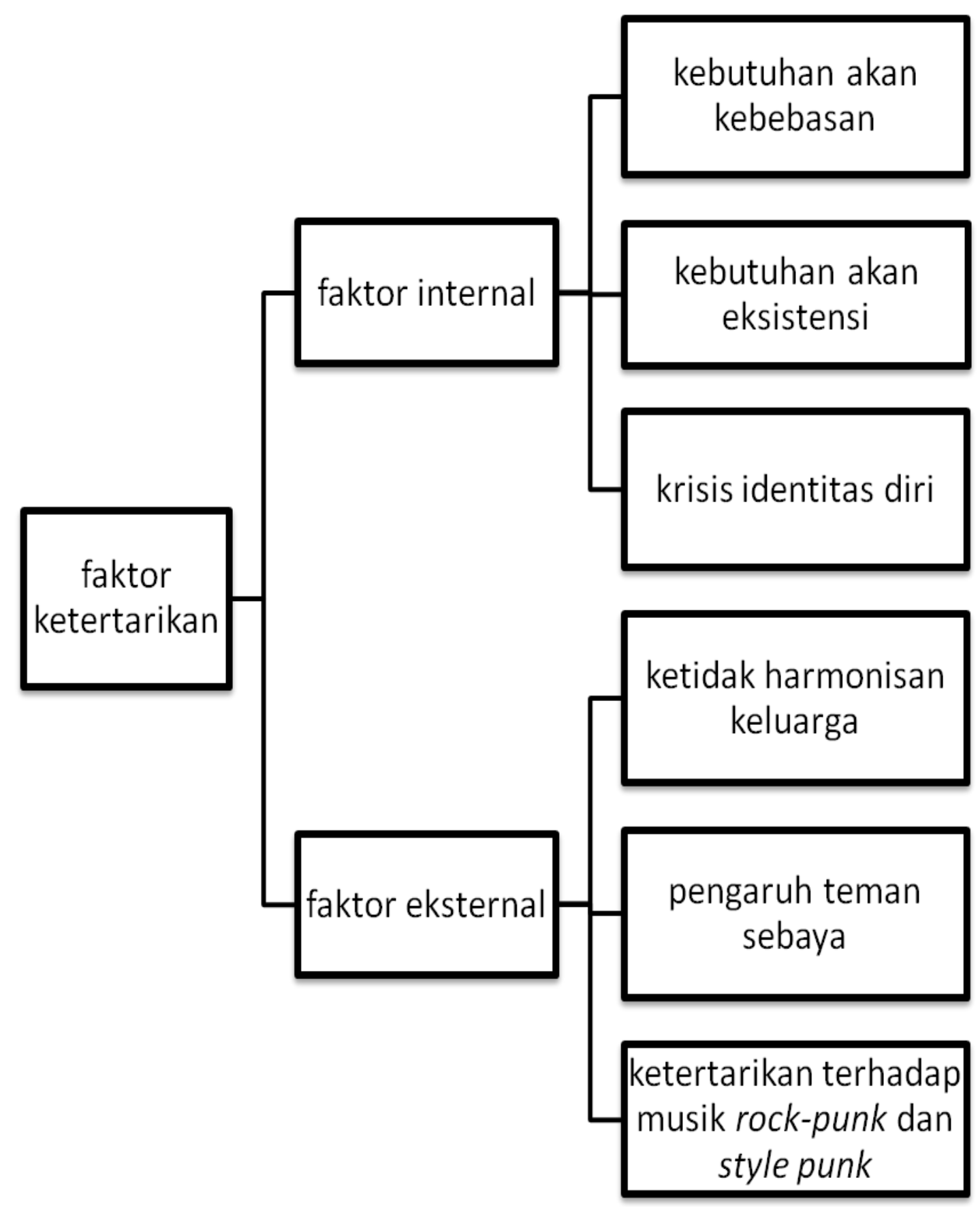




\section{KESIMPULAN DAN SARAN}

\section{KESIMPULAN}

Ketertarikan remaja terhadap punk
terkait dengan faktor-faktor yang mempengaruhinya, yaitu faktor internal dan eksternal. Faktor internal individu mencakup adanya kebutuhan akan eksistensi, kebutuhan akan kebebasan, dan terakhir adalah krisis identitas diri dimana masa remaja dalam masa transisi yang didefinisikan sebagai suatu masa peralihan dari anak-anak menuju dewasa. Dalam masa transisi ini remaja harus berhadapan dengan berbagai macam pilihan yang semuanya itu masih tergolong baru baginya, namun secara langsung maupun tidak langsung remaja dikondisikan untuk memilih, karena remaja dituntut untuk mampu beradaptasi dengan lingkungannya.

Kedua faktor eksternal atau lingkungan individu, mencakup ketidakharmonisan keluarga, teman sebaya dan kegemaran terhadap musik dan style punk. Adanya ketidakharmonisan di dalam hubungan keluarga dengan remaja, yang menyebabkan remaja membutuhkan sebuah wadah yang dapat menampung dan dapat berbagi rasa dengan orang lain yang senasib dengan dirinya, selain itu aturan yang terlalu ketat yang diterapkan oleh orangtua terhadap anak juga dapat mempengaruhi seorang menerjuni dunia punk. Kondisi remaja pada saat itu memiliki semangat muda yang tinggi, serba ingin tahu tentang dunia luar, ingin lebih banyak berekspresi, menginginkan kebebasan, tantangan membutuhkan pengakuan dan ingin selalu mencoba hal baru yang menurut mereka menarik. Sebagai akibatnya yaitu mencoba untuk keluar dari aturan keluarga yang terasa mengikat dan mambatasi. Teman sebaya memperkenalkan melalui musik, penampilan, gaya dan nilai-nilai yang ada di punk

\section{SARAN}

Dari hasil penelitian di atas mengenai ketertarikan remaja terhadap komunitas punk, maka peneliti menyarankan:

1. Masyarakat umum

Bagi masyarakat umumnya perlu memahami punk lebih banyak lagi, di satu sisi ada beberapa hal yang bisa dijadikan bahan renungan bagi kita, perbedaan bukan seharusnya disikapi sebagai sebuah ancaman, karena sesungguhnya komunitas punk hanya ingin eksis dan menjalani hidup dengan apa adanya. Benar atau salah biarlah individu itu yang akan menemukan jawabannya sendiri dengan berjalan seiringnya waktu

2. Peneliti selanjutnya

Kepada peneliti selanjutnya untuk dapat meneliti lebih dalam mengenai komunitas punk ini dan melakukan penelitian tentang faktor-faktor yang diasumsikan mampu mempengaruhi proses internalisasi nilai pada punkers, seperti penerimaan diri, dan intelegensi.

\section{DAFTAR PUSTAKA}

Adrian, A. 2003. Punk sebagai Fenomena Pop Culture. Skripsi (tidakditerbitkan).

Yogyakarta:fakultas Ilmu Budaya

Hurlock, Elizabeth.B. 1980. Psikologi Perkembangan.Jakarta: Penerbit Erlangga Jarvis, Matt.2006. Teori-Teori Psikologi.

Bandung: Penerbit Nusamedia dan nuansa

Mukhlis. Jurnal Psikologi Volume 1 Nomor 2, Desember 2005.Perkembangan identitas diri dalam area agama pada remaja akhir. Diterbitkan oleh : Fakultas Universitas Islam Negeri Sultan Syarif Kasim

Rumini, Sri. 2004. Perkembangan anak dan Remaja. Jakarta: PT.Rineka Cipta 
Poerwandari, Kristi. E. 1998. Pendekatan kualitatif dalam penelitian psikologi. Jakarta: LPSP3 Universitas Indonesia

Santrock, Jhon. W. 2003. Adoslecence. Jakarta: Erlangga

Sarwono, Sarlito.W. 1999. Psikologi Sosial. Jakarta: Balai Pustaka

Sofyan, H. 1999. Hubungan Antara Gaya Pengasuhan Orang tua dan Guru di Sekolah Dengan Eksplorasi dan Komitmen Pada Pembentukan Status Identitas dalam Area Agama Pada Remaja Akhir. Tesis. Tidak dipublikasikan. Bandung: Universitas Padjajaran
Slamet, H. 2010. Teori kelompok sosial. Jakarta: Rineka cipta

Soekanto,S. 2006. Sosiologi suatu pengantar. Jakarta: raja grafindo persada Widya, G. 2010. Punk Ideologi Yang Disalah Pahami. Jogjakarta: Garasi House Of Book

Yusuf, Syamsu. L.N. 2006. Psikologi Perkembangan Anak dan Remaja. Jakarta: PT. Remaja Rosdakarya 
